\title{
From Populism to the 'Plandemic': Why populists believe in COVID-19 conspiracies
}

Jakob-Moritz Eberl $^{\mathrm{a}}{ }^{*}$, Robert A. Huber $^{\mathrm{b}}$ and Esther Greussing ${ }^{\mathrm{c}}$

${ }^{a}$ Department of Communication, University of Vienna, Vienna, Austria

${ }^{b}$ Department of Political Science and Sociology, University of Salzburg, Salzburg, Austria

${ }^{c}$ Institute for Communication Science, TU Braunschweig, Braunschweig, Germany

Submitted for review to Journal of Elections, Public Opinion and Parties on September 14, 2020.

Accepted for publication by Journal of Elections, Public Opinion and Parties on March 17, 2021.

\begin{abstract}
Why are COVID-19 conspiracy theories so prevalent? Particularly, why would some citizens ignore scientific evidence and common logic but, instead, be convinced that COVID-19 was a military experiment or spread by $5 \mathrm{G}$ signals? Why would they believe that Bill Gates had anything to do with it? In this contribution, we argue that populism is at the centre of these beliefs, as the complex nature of the COVID-19 pandemic makes it an ideal playground for populists' opposition to scientific and political elites. We use Structural Equation Models and panel survey data $(n=823)$ from the Austrian Corona Panel Project to test this argument. We demonstrate a negative correlation of populist attitudes with both trust in political and scientific institutions, which, in return, negatively relate to COVID-19 conspiracy beliefs. This results in an overall positive relationship of populist attitudes and conspiracy beliefs, above and beyond political ideology. These findings have important implications for elite communication regarding virus mitigation.
\end{abstract}

Keywords: Populist Attitudes; Coronavirus; Conspiracy beliefs; Pandemic; Trust; Science 


\section{Introduction}

As early as in February 2020, the WHO lamented about having to fight not only the consequences of the COVID-19 pandemic but also those of an "infodemic" in connection to misinformation and conspiracy theories related to the virus (Boberg et al., 2020; Zarocostas, 2020). Arguably right-wing populist leaders worldwide have contributed their fair share to the spread of said "infodemic" by openly disagreeing with scientific experts, public administrators and other political leaders on how to respond to the crisis (Evans and Hargittai, 2020). Furthermore, populist leaders have used a vocabulary of "medical populism", ranging from a simplification of the pandemic to the forging of divisions in times of crisis, as well as to being the source of misinformation and openly supporting conspiracy theories (Lasco, 2020). While Donald Trump, for example, regularly alluded to a "deep state" conspiracy in connection to COVID-19 ${ }^{1}$, a politician of the Alternative for Germany (AfD) claimed in a regional parliament that the virus could be a US-American bioweapon. ${ }^{2}$

A considerable number of citizens around the globe have since taken to the streets to protest COVID-19 containment measures, which they believe to be unnecessary. ${ }^{3}$ Beyond showing open support for far-right ideologies and criticising the supposedly anti-democratic preventive measures against the coronavirus, many also scant conspiracy theories; a.o., that COVID-19 isn't worse than the flu or that it is spread by 5G radio waves (Ahmed et al., 2020). But is there also a connection between populism and citizens' beliefs about the pandemic?

\footnotetext{
${ }^{1}$ https://www.reuters.com/article/us-health-coronavirus-trump-fda/trump-says-without-proof-that-fdadeep-state-slowing-covid-trials-idUSKBN25IOLF

${ }^{2}$ https://correctiv.org/faktencheck/2020/04/01/biowaffe-aus-den-usa-wolfgang-gedeon-verbreitetirrefuehrende-theorie-zu-coronavirus-in-landtag

${ }^{3}$ https://www.bbc.com/news/av/world-europe-53802226
} 
We argue that - beyond and in addition to the widely discussed link between (far-right) ideology and conspiracy belief (see, e.g. van Prooijen et al., 2015; Freeman et al., 2020; Sutton and Douglas, 2020) - it is citizens' populist world-view that fosters conspiracy belief (Castanho Silva et al., 2017; Bergmann, 2018; Oliver and Rahn, 2016; van Prooijen, 2018). In particular, we aim to expand previous work by studying the underlying link between citizens' populist attitudes and their conspiracy belief in the realm of COVID-19. While we do so, we make sure not to conflate populism and ideology, and we explicitly focus on causal mechanisms that should be independent of ideology but entirely a function of populist attitudes, namely the role of trust in political institutions and trust in science. Thus, we specifically pose that populists a) have lower trust in political institutions that implement evidence-based COVID-19 policy measures (i.e., government and parliament) and b) lack trust in science more generally, which makes them particularly prone to anti-science COVID-19 conspiracy theories. Structural Equation Models and data from the Austrian Corona Panel Project are consistent with our theoretical argument.

\section{Populism, Trust, and Conspiracy Theories}

The ideational core of populism (Hawkins and Rovira Kaltwasser, 2018) proclaims three distinct features that explain why citizens may fall for conspiracies: they oppose political and societal elites (anti-elitism), whom they blame for betraying the upright and honest people (people-centrism) in a world that is black and white with no shades of grey (Manichean outlook). This ideational core is independent of political ideology, that is, we observe these traits among left- and right-wing actors, be it parties or individuals (Rooduijn and Akkerman, 2017; Van Hauwaert and Van Kessel, 2018).

We assume that these core features of populism directly inform how populist citizens relate to established political institutions such as the government or the parliament (see Mudde 
and Rovira Kaltwasser, 2012). These institutions represent the established political order, which populists oppose as it is regarded as a manifestation of elite power betraying common citizens rather than serving them. However, these institutions play a central role in mitigating the impact of COVID-19 as well as communicating its dangers; even if their response may sometimes be hesitant, inconsistent, or contradictory (Deslatte, 2020).

Populists' anti-elitist stance, however, does not only target political institutions but is directed at scientific institutions as well (see Wirth et al., 2016). Scholars and academic experts are seen as part of a technocratic elite (Caramani, 2017) that holds power over the questions of "truth" and is not legitimised by the virtuous "people", thus, being part of the plot against them (see Mede and Schäfer, 2020). This antagonism between the populist world-view and scientific evidence has previously been identified as the source of populists' climate change denial (Fraune and Knodt, 2018; Huber, 2020; Huber et al., 2020) and vaccine hesitancy (Kennedy, 2019). It becomes even more relevant in times where scientific knowledge forms the basis of policy decisions but is not at all easy to follow as it is often characterised by uncertainty, unpredictability, and incomplete control (Funtowicz and Ravetz, 1993).

The nature of the political response to the global pandemic almost invites populists to oppose these measures and to rather believe in elite-conspiracies. Given the large uncertainty and immense pressure to act, most policies responding to the virus seem elite-driven top-down policies with lower levels of parliamentary debate. Increased media visibility of epidemiologists, virologists and other scientific experts (Wormer, 2020) make it relatively easy for sceptics to claim that sudden and oftentimes strict government responses to COVID-19 were a result of backroom deals between powerful elites (may they be from politics, academia, "big pharma", or famous philanthropists).

While throughout history people have been prone to conspiracy theories during impactful societal crisis situations (van Prooijen and Douglas, 2017), evidence suggests that 
populists may be particularly prone to conspiracy theories that are built on the accusation of abuse of power by elites (Castanho Silva et al., 2017). On social media, widely posted or shared COVID-19 conspiracy theories, such as the contents of the infamous "Plandemic" movie (Moran, 2020), combine the criticism of political elites with that of technocratic elites. This leads us to suspect two causal pathways of how populism and COVID-19 conspiracy belief may relate. All-in-all, we expect an effect of populism on COVID-19 conspiracy beliefs running through individuals' (1) trust in political institutions and (2) trust in science and research.

\section{Data, Measures and Method}

Our data focuses on Austria, which is a particularly interesting case to test our theory. While previous research on conspiracy beliefs was often focussed on two-party systems such as the US and the UK (van Prooijen and Douglas, 2018), Austria represents a good example of an increasingly common situation in many Western parliamentary democracies, where mainstream parties are being challenged by at least one major populist party (if not more).

To test our theoretical arguments outlined above, we use data from the Austrian Corona Panel Study. This study surveys the Austrian voting-age population. Respondents in this panel are selected based on the following key demographics: age, gender, gender $\mathrm{x}$ age, region (province), educational level, and municipality size. The quota sample was structured to closely represent the Austrian population (Kittel et al., 2020a, 2020b). We focus on 823 respondents who took part in Wave 6 and Wave 9 of the study, as these waves provide the measures of populist attitudes, trust in political institutions, trust in science as well as several items of conspiracy belief. Wave 6 was fielded between 1 May and 6 May, while Wave 9 was fielded between 23 May and 27 May 2020. 


\section{Dependent variable}

As Sutton and Douglas (2014: 256) explain, "[t]o believe in any conspiracy theory is to believe that authorities can be malevolent, that they can conceal their evil-doing, and that official explanations for major events may be lies". To capture underlying conspiracy beliefs, respondents were asked to what extent they considered eight statements about COVID-19 to be true or false, with a scale ranging from 1 (very certain that this is false) to 5 (very certain that this is true) and a middle category 3 (unsure, whether that is true or false). While for most statements, a higher score reflects conspiracy beliefs, items C3 and C5 were phrased the opposite way. Table 1 provides the wording, factor loadings from a confirmatory factor analysis embedded in a structural equation environment, and the share of respondents prone to these beliefs according to our sample. In total, a staggering $69 \%$ of respondents were "unsure" about at least one conspiracy theory, or were even "rather certain" or "very certain" that it was actually correct. Almost $3 \%$ of our respondents, furthermore, fail to reject any of the eight conspiracy theories queried. The factor loadings generally suggest that all the items load reasonably well on the underlying construct.

Table 1: Corona Conspiracy-Belief

\begin{tabular}{|l|l|l|l|}
\hline Item & Wording & Loading & $\begin{array}{l}\text { Share of } \\
\text { Respondents prone } \\
\text { to Conspiracy } \\
\text { Beliefs (in \%) }\end{array}$ \\
\hline C1 & $\begin{array}{l}\text { The vaccine against the coronavirus has } \\
\text { already been developed but is being held back } \\
\text { by large pharmaceutical companies }\end{array}$ & 0.85 & $28.68(21.99)$ \\
\hline C2 & $\begin{array}{l}\text { The vaccine against the coronavirus has } \\
\text { already been developed but is being held back } \\
\text { by the government. }\end{array}$ & 0.85 & $23.33(18.47)$ \\
\hline C3 & $\begin{array}{l}\text { The vaccine against the coronavirus is } \\
\text { currently being developed, and there are test } \\
\text { vaccines that cannot be used before they have }\end{array}$ & -0.44 & $33.78(23.21)$ \\
\hline
\end{tabular}




\begin{tabular}{|l|l|l|l|}
\hline & been extensively tested. & & \\
\hline C4 & $\begin{array}{l}\text { The coronavirus is a bioweapon that was } \\
\text { deliberately developed to harm humans. }\end{array}$ & 0.91 & $35.48(24.30)$ \\
\hline C5 & $\begin{array}{l}\text { The coronavirus is a natural infectious disease } \\
\text { that has spread worldwide and caused a } \\
\text { pandemic. }\end{array}$ & -0.50 & $40.10(21.63)$ \\
\hline C6 & $\begin{array}{l}\text { The coronavirus was accidentally released } \\
\text { during a secret US military experiment. }\end{array}$ & 0.91 & $28.68(23.21)$ \\
\hline C7 & $\begin{array}{l}\text { Bill Gates wants to vaccinate humanity by } \\
\text { force in order to earn a lot of money. }\end{array}$ & 0.81 & $33.66(20.78)$ \\
\hline C8 & $\begin{array}{l}\text { The new 5G transmitter masts are responsible } \\
\text { for the spread of the coronavirus. }\end{array}$ & 0.73 & 13.24 (11.06) \\
\hline $\begin{array}{l}\text { Notes: Estimator 'WLSM.' Goodness of fit: } X^{2}(228, n=823)=1103.1 ; p>0.05 ; \text { CFI = 0.970; } R M S E A= \\
\text { 0.056; SRMR } 0.063 . \text { Share of respondents prone to conspiracy beliefs is the share of all respondents who } \\
\text { either support a conspiracy theory or are uncertain whether it is true or not. Shares in brackets are those } \\
\text { who are uncertain if the statement is true or not. Figure Al in the Appendix shows the correlation between } \\
\text { the items. }\end{array}$
\end{tabular}

\section{Independent variables: Populism, trust in political institutions, trust in science and research, and ideology}

We utilise a standard scale to capture populism, namely the CSES Module 5 scale (Hobolt et al., 2016). Based on Akkerman et al. (2014), this scale captures the aforementioned ideational definition of populism. Questions range from attitudes towards elites to morality in politics, thereby neatly capturing all three dimensions of populism. Empirically testing the scale, Castanho Silva and colleagues (2019) show the scale works well and particularly captures antielitism. Populist attitudes were recorded in a previous wave (Wave 6) as compared to our dependent variable. This allows for a clearer temporal order and thus a more causal argument about the relationship between populists attitudes and conspiracy beliefs.

Also measured in Wave 6 are our two mediators: respondents' trust in political institutions, namely trust in parliament and trust in government, as well as their trust in science and research. The scale ranges from 0 (do not trust at all) to 10 (completely trust). 
We additionally include several control variables to isolate the effect of populism on COVID-19 conspiracy belief. ${ }^{4}$ Notably, we include political ideology and ideological extremism, which we proxy with left-right self-placement and its centred and squared term. Often, populism comes in combination with a certain ideological leaning, for example, with anti-immigration positions (for right-wing populism) or anti-market positions (for left-wing populists). Often, studies do not measure populist attitudes directly or conflate trust in politics, ideological extremism, and other concepts related to populism (Akkerman et al., 2014). Thus, being able to disentangle these two concepts is essential to understand the role of populism.

\section{Estimation Strategy}

We rely on structural equation models (SEM) to simultaneously measure latent variables and estimate their interconnectedness through regression analyses. SEM provides several key advantages over classic regression analyses when using latent constructs. First of all, we capture several latent structures within one model. This would allow understanding the interconcept correlation between the concepts and potentially adjust for it. SEM equally allows to capture and model the covariation of other, manifest or latent, variables. Second, SEM allows us to draw and test more complex theoretical models, which allow for indirect paths, and thus several dependent variables, which is important given our theoretical expectations. We model the structural equation model using the R package lavaan (Rosseel, 2012). We use the 'WLSM' estimator, which allows for categorical variables.

\footnotetext{
${ }^{4} \mathrm{We}$ do not apply sample weights since our variables stem from different waves of the panel. Since we control for central variables used to create the weights, our estimation already adjusts for slight deviations from the population. Correcting for either weights does not affect the results presented in this article.
} 


\section{Results}

Figure 1 shows the bivariate distribution of populism and COVID-19 conspiracy belief, providing first evidence of the association between the two variables $(r=0.41)$. Individuals with higher levels of populist attitudes are also more likely to believe in conspiracy theories. In the aggregate, we observe these two variables are associated. However, our paper aims at understanding the causal mechanisms linking these two concepts in more detail. Thus, we are interested in whether this relationship is mediated by trust in political institutions and trust in science as well as whether it holds true irrespective of citizens' political ideology.

Figure 1 Bivariate Distribution of Populism and Conspiracy Belief

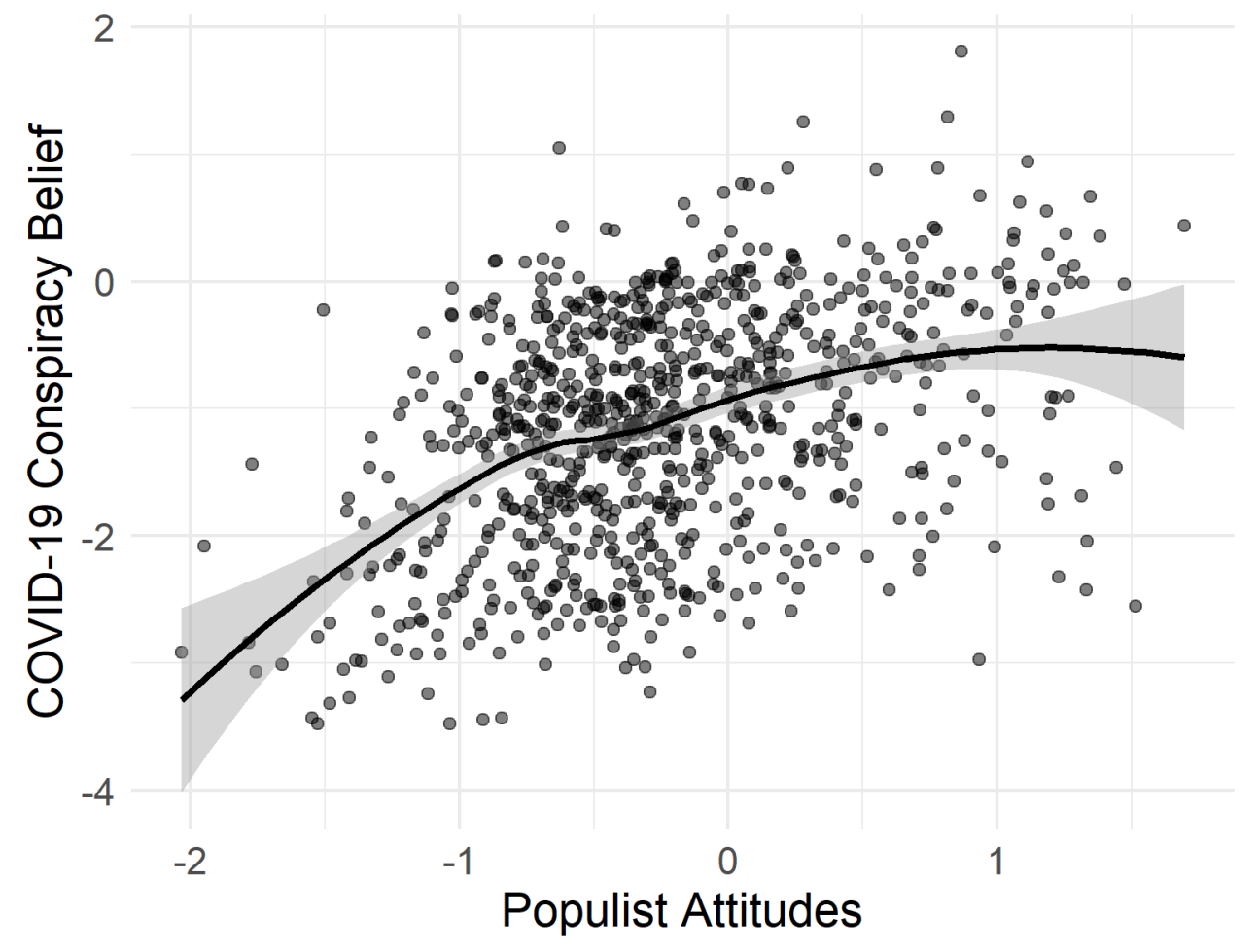

Note: Line is a local polynomial regression line ('loess').

Figure 2 summarises the core findings of our argument: populism indirectly affects COVID19 conspiracy beliefs through trust in political and scientific institutions. The evidence lends strong support for both paths. First, populist attitudes negatively correlate with trust in the 
government and the parliament. Trust in these political institutions, in return, negatively relates to individuals' probability to believe in COVID-19 conspiracies. In other words, trusting political institutions, which are central in the mitigation and communication of COVID-19 risks, decreases the probability that respondents believe in conspiracy theories, such as that $5 \mathrm{G}$ is causing COVID-19. This results in a standardised total effect size of populism through institutional trust of 0.19 , which is statistically significant.

Second, higher populist attitudes relate to lower trust in science and research, which consequently decreases COVID-19 conspiracy belief. Given the importance of science and scientists in the communication of the dynamics of the COVID-19 outbreaks as well as their role in informing key policies, it makes sense that citizens who distrust the institution of science and research do not trust in the phenomenon it tries to address either. Thus, an increase in populist attitudes would result in an increase in COVID-19 conspiracy belief (the standardised total effect size for this path is 0.10 and statistically significant).

All-in-all, this suggests that populism is an important predictor of citizens' conspiracy thinking in respect to the COVID-19 pandemic. The total effect of populism (that is the combination of both paths) is statistically significant and large in size (standardised regression coefficient is 0.29 ). 
Figure 2 Structural Equation Model

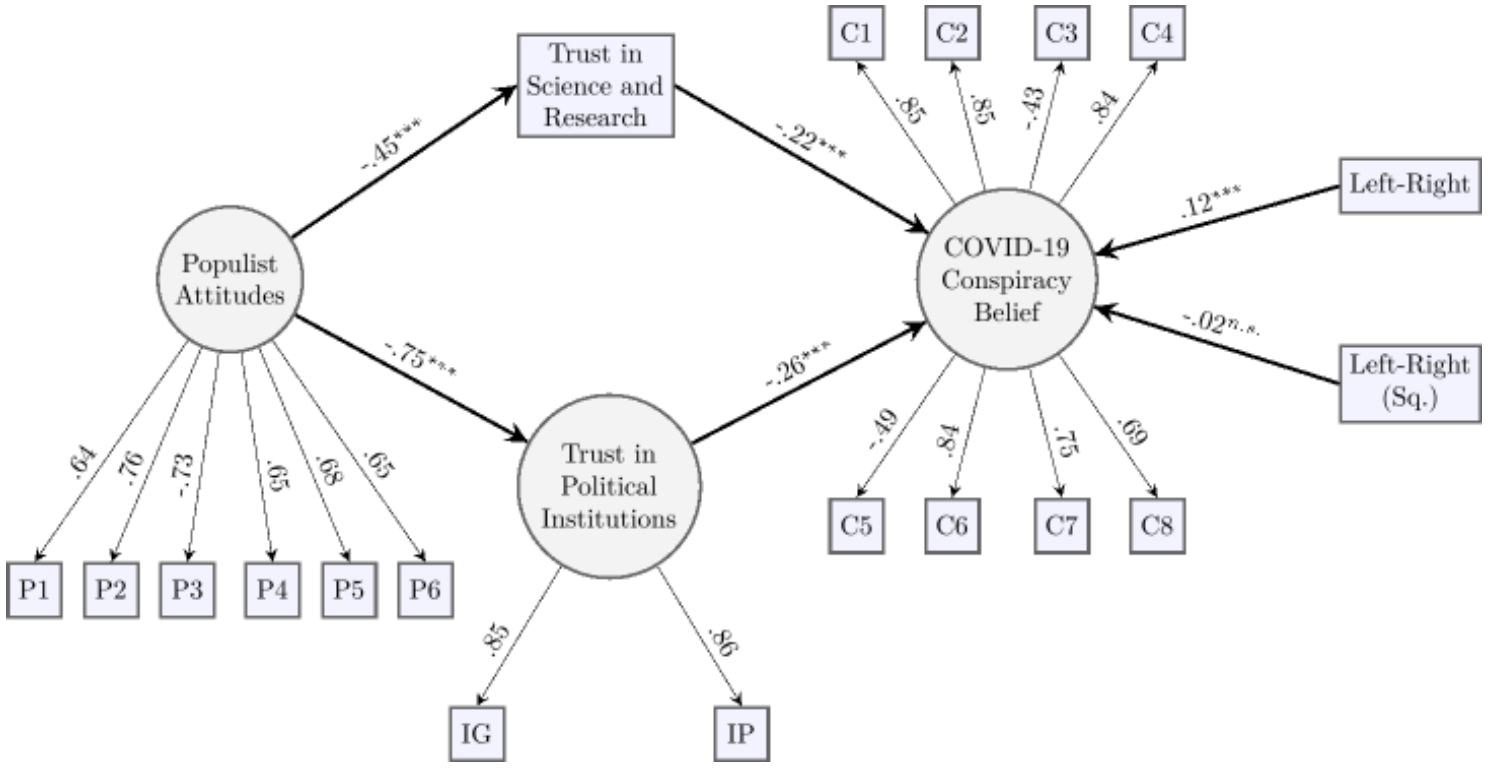

Note: Bold arrows refer to regression paths; other arrows are measurement paths. Entries are standardised factor loadings and regression coefficients based on estimations with a 'WLSM' estimator in lavaan. *** on regression paths indicate that $p<0.001$, n.s. indicate $p>0.05$. We included age, education, gender, political ideology, political interest, a dummy for preconditions and a dummy for respondents in Vienna. These controls are included in all regression paths. We only show political ideology for the main outcome variable. Please consult Table Al in the Appendix for the regression tables. We report robust goodness of fit indicators given the use of 'WLSM.' Goodness of fit: $X^{2}(228, n=823)=1103.1 ; p<0.05 ; C F I=0.970 ; R M S E A=0.056 ;$ SRMR $=0.063$.

In the introduction, we emphasised the potential role of ideology both within the supply-side as well as within the citizen response to COVID-19. While, more generally, extreme ideology is shown to relate to conspiracy belief (van Prooijen et al., 2015), most openly sceptical of COVID-19 were politicians like Donald J. Trump or Jair Bolsonaro, who are typical representatives of right-wing populism. Similarly, in Europe, the populist radical right AfD and Austrian Freedom Party (FPÖ) are two standard cases that took more sceptical stances on COVID-19 (e.g., FPÖ, 2020a). To disentangle the effects of populism and ideology, our models thus include left-right self-placement and its squared term (measuring extremism). As shown in Figure 2, left-right self-placement - but not its squared term - is positively associated with COVID-19 conspiracy belief. In addition to that, throughout the model, the standardised regression coefficients of ideology are substantially smaller than those of populism. 


\section{Robustness Checks}

To assess the robustness of these findings, we conduct a series of additional tests. First, we exclude voters of the populist radical right FPÖ, which tapped into conspiracy theories, like forced vaccinations (FPÖ, 2020b).

Second, we recode all conspiracy theories into dummies that capture whether somebody rejects the conspiracy theory or not. While the ordinal five-point scale provides more information, one could argue that it also induces measurement error. On the one hand, we substitute the ordinal variables with dichotomised variables in the confirmatory factor analysis. On the other hand, we created an additive index which captures the number of conspiracy theories an individual does not reject.

Finally, we include a direct path linking populism and COVID-19 conspiracy beliefs to understand whether the two mechanisms we propose are the only paths through which populism relates to the outcome.

All tests confirm the robustness of our findings (see Table A2, A3, A4 and A5 in the Appendix). Our findings do not change when excluding FPÖ voters or when recoding the variables. The direct path of populist attitudes returns a positive but insignificant coefficient. This indicates that our two proposed mechanisms capture the core relationship of populism and COVID-19 conspiracy theories, above and beyond political ideology.

\section{Conclusion \& Discussion}

Among others, results have shown that $69 \%$ of respondents fail to reject all of the eight conspiracy theories surveyed in this study. Even if these eight theories are largely "harmless", this finding is insofar problematic as previous research suggests that belief in one conspiracy may soon lead to belief in other conspiracies (Lewandowsky et al., 2013). Not clearly rejecting the COVID-19 conspiracies above may thus make the slope to more dangerous ones (e.g., 
'QAnon') significantly more slippery.

Our main argument relates to the relationship between respondents' populist attitudes and their COVID-19 conspiracy belief. In fact, we identify two causal paths: Populist attitudes decrease trust in political institutions (1) as well as trust in science and research (2), both negatively relate to COVID-19 conspiracy belief. While right-wing populist actors, in particular, seem to be actively contributing to the COVID-19 conspiracy theory supply as well as its spread, our individual level evidence suggests that right-wing ideology plays only a subordinate role to populist attitudes (see, also Oliver and Wood, 2014).

The findings have several important implications. First, citizens do not necessarily follow party elites in their conspiracy beliefs. On a supply level, the FPÖ in Austria is by far the most sceptical party regarding COVID-19. However, we observe that populist attitudes, which appear across the left-right spectrum, are more important in predicting these COVID-19 attitudes. This has substantial implications for our response to this scepticism, as these conspiracy beliefs are not restricted to fringe ideologies. Second, while it might appear that right-wing populist governments have particularly struggled with fighting the pandemic, our results suggest that claiming that "coronavirus could kill off populism" 5 might be too shortsighted. As acceptance of COVID-19 mitigation measures is also declining in countries led by non-populist governments (Kittel et al., 2020b), and as (right-wing) populist leaders have monopolised on discontent with COVID-19 policies and related conspiracy belief, there is reason to believe that support for populist challengers in these countries could even increase in the course of 2020 and beyond. Third, the results highlight that effective communication about COVID-19 may not only try to correct existing misperceptions (Lyons et al., 2019) but to break the mechanism that leads to these misperceptions. That is, communicative efforts should not

\footnotetext{
${ }^{5}$ https://www.ft.com/content/3bcf2b5e-e5f1-48e4-bb15-cd29615a9198
} 
let political and scientific institutions appear as a detached elite. Instead, politicians and scientists might rather engage in an open and transparent conversation with the public, acknowledging lay peoples' needs and concerns, in order to make complex information accessible and to avoid information gaps that can be easily filled with various forms of misinformation (Brennen et al., 2020).

Overall, our study advances the understanding of causal mechanisms that lead the way from populism to the 'Plandemic'. Since populist attitudes might not be the only or even strongest predictor of COVID-19 conspiracy belief, probing other known relationships in this regard will be an important avenue for future research to further inform adequate policy responses and communication strategies in unprecedented crisis situations such as the emergence of the novel coronavirus.

\section{Funding}

The data collection of the Austrian Corona Panel Project (ACPP) has been made possible by COVID-19 Rapid Response Grant EI-COV20-006 of the Wiener Wissenschafts- und Technologiefonds (WWTF), financial support by the rectorate of the University of Vienna, and funding by the FWF Austrian Science Fund (P33907; Elise Richter Grant AV561). Further funding by the Austrian Social Survey (SSÖ), the Vienna Chamber of Labour and the Federation of Austrian Industries is gratefully acknowledged. 


\section{References}

Ahmed, Wasim, Josep Vidal-Alaball, Joseph Downing, and Francesc López Seguí. (2020) "COVID-19 and the 5G Conspiracy Theory: Social Network Analysis of Twitter Data." Journal of Medical Internet Research 22:e19458.

Akkerman, Agnes, Cas Mudde, and Andrej Zaslove. (2014) "How Populist Are the People? Measuring Populist Attitudes in Voters." Comparative Political Studies 47:1324-1353.

Bergmann, Eirikur. 2018. Conspiracy \& populism: the politics of misinformation. New York, NY: Springer Berlin Heidelberg.

Boberg, Svenja, Thorsten Quandt, Tim Schatto-Eckrodt, and Lena Frischlich. (2020) "Pandemic Populism: Facebook Pages of Alternative News Media and the Corona Crisis -- A Computational Content Analysis." arXiv:2004.02566 [cs]. http://arxiv.org/abs/2004.02566 (Accessed September 11, 2020).

Brennen, J. Scott, Felix M. Simon, Philip N. Howard, and Rasmus Kleis Nielsen. (2020) "Types, Sources, and Claims of COVID-19 Misinformation." Reuters Institute 7:1-13.

Caramani, Daniele. (2017) "Will vs. Reason: The Populist and Technocratic Forms of Political Representation and Their Critique to Party Government." American Political Science Review 111:54-67.

Castanho Silva, Bruno, Sebastian Jungkunz, Marc Helbling, and Levente Littvay. (2019) "An Empirical Comparison of Seven Populist Attitudes Scales." Political Research Quarterly 106591291983317.

Castanho Silva, Bruno, Federico Vegetti, and Levente Littvay. (2017) "The Elite Is Up to Something: Exploring the Relation Between Populism and Belief in Conspiracy Theories." Swiss Political Science Review 23:423-443.

Deslatte, Aaron. (2020) "The Erosion of Trust During a Global Pandemic and How Public Administrators Should Counter It." The American Review of Public Administration 50:489-496.

Evans, John H., and Eszter Hargittai. (2020) “Who Doesn't Trust Fauci? The Public's Belief in the Expertise and Shared Values of Scientists in the COVID-19 Pandemic." Socius: Sociological Research for a Dynamic World 6:237802312094733.

FPÖ. (2020a) "FPÖ - Fürst zu Corona-U-Ausschuss: Der Tag der Abrechnung wird kommen!" https://www.ots.at/presseaussendung/OTS_20200529_OTS0080/fpoe-fuerst-zu-coronau-ausschuss-der-tag-der-abrechnung-wird-kommen (Accessed September 11, 2020).

FPÖ. (2020b) "FPÖ - Kickl: Schwarz-grüner Corona-Wahnsinn nimmt wieder rasant Fahrt auf - auch der ORF ist gefordert." https://www.ots.at/presseaussendung/OTS_20200826_OTS0072/fpoe-kickl-schwarzgruener-corona-wahnsinn-nimmt-wieder-rasant-fahrt-auf-auch-der-orf-ist-gefordert.

Fraune, Cornelia, and Michèle Knodt. (2018) "Sustainable energy transformations in an age of populism, post-truth politics, and local resistance." Energy Research \& Social Science 43:1-7. 
Freeman, Daniel et al. (2020) "Coronavirus conspiracy beliefs, mistrust, and compliance with government guidelines in England." Psychological Medicine 1-13.

Funtowicz, Silvio O., and Jerome R. Ravetz. (1993) “Science for the post-normal age." Futures 25:739-755.

Hawkins, Kirk A., and Cristóbal Rovira Kaltwasser. (2018) "Introduction: the ideational approach.” In: Kirk A. Hawkins, Ryan E. Carlin, Levente Littvay, and Cristóbal Rovira Kaltwasser (eds) The Ideational Approach to Populism: Concept, Theory, And Method. Routledge.

Hobolt, Sara B., Eva Anduiza, Ali Carkoglu, Georg Lutz, and Nicolas Sauger. 2016. CSES Module 5: Democracy Divided? People, Politicians and the Politics of Populism. CSES Planning Committee Module 5 Final Report.

Huber, Robert A. (2020) "The role of populist attitudes in explaining climate change skepticism and support for environmental protection." Environmental Politics 29:959982.

Huber, Robert A., Esther Greussing, and Jakob-Moritz Eberl. (2020) "Populist Attitudes and Climate Scepticism: It's all about Science and Political Institutions." SocArXiv. https://osf.io/m82kg (Accessed October 2, 2020).

Kennedy, Jonathan. (2019) "Populist politics and vaccine hesitancy in Western Europe: an analysis of national-level data.” European Journal of Public Health 29:512-516.

Kittel, Bernhard et al. (2020a) "Austrian Corona Panel Project (SUF edition)." https://data.aussda.at/citation?persistentId=doi:10.11587/28KQNS (Accessed August 17, 2020).

Kittel, Bernhard et al. (2020b) "The Austrian Corona Panel Project: monitoring individual and societal dynamics amidst the COVID-19 crisis." European Political Science. http://link.springer.com/10.1057/s41304-020-00294-7 (Accessed February 14, 2021).

Lasco, Gideon. (2020) "Medical populism and the COVID-19 pandemic." Global Public Health 1-13.

Lewandowsky, Stephan, Klaus Oberauer, and Gilles E. Gignac. (2013) "NASA Faked the Moon Landing--Therefore, (Climate) Science Is a Hoax: An Anatomy of the Motivated Rejection of Science.” Psychological Science 24:622-633.

Lyons, Benjamin, Vittorio Merola, and Jason Reifler. (2019) "Not Just Asking Questions: Effects of Implicit and Explicit Conspiracy Information About Vaccines and Genetic Modification." Health Communication 34:1741-1750.

Mede, Niels G., and Mike S. Schäfer. (2020) "Science-related populism: Conceptualizing populist demands toward science." Public Understanding of Science 29:473-491.

Moran, Patrick. (2020) "Social Media: A Pandemic of Misinformation." The American Journal of Medicine S0002934320305192. 
Mudde, Cas, and Cristóbal Rovira Kaltwasser, eds. 2012. Populism in Europe and the Americas: Threat or corrective for democracy? Cambridge: Cambridge University Press.

Oliver, J. Eric, and Wendy M. Rahn. (2016) "Rise of the Trumpenvolk: Populism in the 2016 Election." The ANNALS of the American Academy of Political and Social Science 667:189-206.

Oliver, J. Eric, and Thomas J. Wood. (2014) "Conspiracy Theories and the Paranoid Style(s) of Mass Opinion.” American Journal of Political Science 58:952-966.

van Prooijen, Jan-Willem. (2018) "Populism as political mentality underlying conspiracy theories." In: Bastiaan T. Rutjens and Mark J. Brandt (eds) Belief Systems and the Perception of Reality. New York: Taylor and Francis, [2019] | Series: Current issues in social psychology:

Routledge https://www.taylorfrancis.com/books/9781351629089/chapters/10.4324/978131511490 3-6 (Accessed February 16, 2021).

van Prooijen, Jan-Willem, and Karen M. Douglas. (2018) "Belief in conspiracy theories: Basic principles of an emerging research domain." European Journal of Social Psychology 48:897-908.

van Prooijen, Jan-Willem, and Karen M Douglas. (2017) "Conspiracy theories as part of history: The role of societal crisis situations.” Memory Studies 10:323-333.

van Prooijen, Jan-Willem, André P. M. Krouwel, and Thomas V. Pollet. (2015) "Political Extremism Predicts Belief in Conspiracy Theories." Social Psychological and Personality Science 6:570-578.

Rooduijn, Matthijs, and Tjitske Akkerman. (2017) "Flank attacks: Populism and left-right radicalism in Western Europe." Party Politics 23:193-204.

Rosseel, Yves. (2012) "lavaan: An R package for structural equation modeling." Journal of Statistical Software 48:1-36.

Sutton, Robbie M, and Karen M Douglas. (2020) "Conspiracy theories and the conspiracy mindset: implications for political ideology." Current Opinion in Behavioral Sciences 34:118-122.

Sutton, Robbie M, and Karen M. Douglas. (2014) "Examining the monological nature of conspiracy theories." In: Jan-Willem van Prooijen and Paul A. M. van Lange (eds) Power, Politics, and Paranoia: Why People Are Suspicious of their Leaders. Cambridge: Cambridge University Press http://ebooks.cambridge.org/ref/id/CBO9781139565417 (Accessed September 11, 2020).

Van Hauwaert, Steven M., and Stijn Van Kessel. (2018) "Beyond protest and discontent: A cross-national analysis of the effect of populist attitudes and issue positions on populist party support." European Journal of Political Research 57:68-92.

Wirth, Werner et al. (2016) "The appeal of populist ideas, strategies, and styles: A theoretical model and research design for analyzing populist political communication." https://www.zora.uzh.ch/id/eprint/127461 (Accessed July 28, 2020). 
Wormer, Holger. (2020) "German Media and Coronavirus: Exceptional Communication-Or Just a Catalyst for Existing Tendencies?” Media and Communication 8:467-470.

Zarocostas, John. (2020) "How to fight an infodemic." The Lancet 395:676. 